\title{
Incidence of ectoparasite in chiltan wild goat (Artiodactyla: Caprinae) native of Hazarganji chiltan national park (HCNP), Balochistan, Pakistan
}

\author{
Maryam Haneef ${ }^{1}$, Asmatullah Kakar ${ }^{2 *}$, Mahrukh Naseem ${ }^{2}$, Nazir \\ Ahmad Kurd ${ }^{3}$, Nosheen Rafiq ${ }^{4}$, Basra Kakar ${ }^{5}$ and Sharif Uddin ${ }^{3}$ \\ 1. Islamia Girls Degree College, Quetta-87300, Pakistan \\ 2. Department of Zoology, University of Balochistan, Quetta-87300-Pakistan \\ 3. Department of Wild life (HCNP), Balochistan, Quetta-87300-Pakistan \\ 4. Department of Zoology, SBK Women University, Quetta-87300-Pakistan \\ 5. Department of Botany, University of Balochistan, Quetta-87300-Pakistan \\ *Corresponding author's email: asmardanzai@yahoo.com \\ Citation
}

Maryam Haneef, Asmatullah Kakar, Mahrukh Naseem, Nazir Ahmad Kurd, Nosheen Rafiq, Basra Kakar and Sharif Uddin. Incidence of ectoparasite in chiltan wild goat (Artiodactyla: Caprinae) native of Hazarganji chiltan national park (HCNP), Balochistan, Pakistan. Pure and Applied Biology. Vol. 8, Issue 1, pp389-396.

http://dx.doi.org/10.19045/bspab.2018.700198

\begin{tabular}{llll}
\hline \hline Received: 07/08/2018 & Revised: 03/12/2018 & Accepted: 06/12/2018 & Online First: 08/12/2018 \\
\hline \hline
\end{tabular}

\section{Abstract}

The ectoparasite study is of great value to monitor its effect on the health and care of wild goat population. A study was conducted to determine the ectoparasites of chiltan wild goat (Capra aegagrus chialtanensis Lydekker, 1913) in Hazarganji chiltan national park (HCNP) between the months of May to October, 2016. Hard ticks (Ixodidae) species were found in HCNP ground area where high mobility of chiltan goats were observed. It can be pretended in the light of literature that fully or partly fed ticks might cast off from chiltan wild goats. The prevalent ectoparasites in this study were from the two genera of tick viz Hyalomma, and Rhipicepalus (Boophalus). Result showed high prevalence (57.14\%), (54.16\%) for the male Hyalomma excavatum and $H$. anatolicum viz $46 \%, 43 \%$ for the two female species respectively. While 100 percent prevalence were observed for male Rhipicepalus (Boophalus) microplus and $R$. (B.) appendiculatus respectively. Females of the two ticks species were not found in the present study. Moreover, total percent sex-wise count of ticks indicated $78.0 \%$ for male ticks compare to females $(45.0 \%)$. It was concluded that population of tick parasites was high noted in the present study, and this could affect the prosperity and fecundity of chiltan wild goats. Therefore, to reduce ectoparasites burden and its impact on the fertility and health status, planning of strong policy aiming at creating awareness about the value of wildlife and control of ectoparasites with sustainable veterinary services is required.

Keywords: Balochistan; Chiltan wild goat; Hard ticks; Hilly-region; Incidence

Introduction

The Chiltan wild goat, Capra aegagrus chialtanensis (Ladekker, 1913) is existed only in the highlands of north-west of Balochistan province [1, 2]. Despite its world-wide value, it has not been explored properly nor has it been identified correctly [3-5]. These wild goats were confined to the hill ranges of Chiltan, Murdar, and Kohi Maran in Balochistan as it was an intellection until the late seventies [7]. Presently, it is only reported in the 
Hazarganji-Chiltan National Park, situated some $20 \mathrm{~km}$ from Quetta city, the capital of the Balochistan [6]. Ladekker [9] first described this animal as distinct subspecies, Capra falconeri chialtanensis. Other scientists cited in Roberts [9] and Schaller [10] suggested that it might be a hybrid between the straight-horned markhoor ( $C$. falconeri jerdoni) and the wild goat or a markhor and a domestic goat. Schallar and Khan [11] and Schaller [10], however, have studied populations of various species, and based on horn morphology concluded that they (Capra falconeri chialtanensis) are in fact Capra aegagrus chialtanensis. It was concluded that it does not merit sub-specific status because intermediate forms exist between this species and a typical wild goat.

Various species of ticks are known to be found in the wild animals including wild goats (Capra hircus aegagrus), but the intensity of infestation and the effects of ticks on their hosts are poorly studied [11]. Studies concerning ticks are of significant importance to assess the dispersion and composition of species affecting animals [9]. The comparative lists of ixodid ticks of different host are described by several authors [10]. Hoogstral and Wassef [15], Hoogstraal and Valdez [16] reported 17 species of ixodid and argasid ticks from wild sheep (Ovis orientalis) and wild goats (Capra hircus aegagrus) in Iran. Rahbari and Nabian [17] also have described Rhipicephalus (Boophilus) kholsi from wild goats (Capra hircus aegagrus) in Iran.

Information on chiltan wild goat ectoparasites is poor and lacking. Similarly, the scientific knowledge on the present status of chiltan wild goat is too old and does not reflect the current population and habitat details. Ladekker [8] first described this animal as distinct sub-species, (Capra falconeri chialtanensis). Other scientists cited in Roberts [9] and Schaller [10] suggested that it might be a hybrid between the straight-horned markhor ( $C$. falconeri jerdoni) and the wild goat or a markhor and a domestic goat. Schallar and Khan [11] and Schaller [10], however, have studied populations of various species and based on horn morphology concluded that they (C.f. chialtanensis) are in fact Capra aegagrus chialtanensis. It was concluded that it does not merit sub-specific status because intermediate forms exist between this species and a typical wild goat.Though Schaller [10] has changed the status of the chiltan goat, and some scientists and local experts still do not agree with his arguments and declare the species to be, in fact, a markhor.

Bowman [13] highlighted some environmental condition rarely may possibly develop ectoparasites such as fleas, lice, and in particular ticks on the skin and wool of wild goat which may cause severe hide corrade. In the present survey during 2016. The ectoparasites of chiltan wild goat (C. a. chialtanensis) were detected and identified. Overall number (adult male and female, lamb and trophy) of the goat were counted. On the health and welfare of this exotic species not a single report has been published formally nor in the past have any remarkable works been done on ectoparasites of $C$. a. chialtanensis in HCNP, Quetta. The local persons also reported the grazing of domestic herd of goats in the park area, perhaps the ectoparasites might be spreaded from domestic herd to chiltan wild goat herds. To our cognition, this is the first significant report on ticks infests wild goats which covers the southwestern region of Balochistan, thus represent a geographic record.

\section{Materials and methods Area of study}

Investigations were carried out in Hazarganji Chiltan National Park (HCNP) found in the districts of Quetta and Mustang, Baluchistan province (Figure 1), Pakistan. It is located some $20 \mathrm{~km}$ south west of metropolitan city Quetta. The area is a high land comprised on low, uplands and peak with an elevation (1680 $\mathrm{m}$ to $3313 \mathrm{~m}$ ) and coordinates of $29^{\circ} 59^{\circ}-30^{\circ} 07^{\top} \mathrm{N}, 66^{\circ} 24^{`}$ $66^{\circ} 54^{\circ} \mathrm{E}$. The original land is 12571 ha 
notified in 1980 include Hazarganji state forest (2203 ha) and chiltan protected forest (10368 ha). Extra land were later added enlarged the park area to an estimated 15555 ha. Of this total, 5191 ha are in Quetta and 10364 ha in Mastung districts.

\section{Climate}

The climate of HCNP is semi-arid. The long-term average annual total precipitation is about $240 \mathrm{~mm}$, most of which falls in winter. The highest temperature recorded in summer reach to $40 \mathrm{C}^{\circ}$ and has very cold winters $\left(<-12{ }^{\circ} \mathrm{C}\right)$ in which the severity of the cold is exacerbated by elevation and wind speed The average relative humidity in winter is about $30-40 \%$ and in summer 20-30\%.

\section{Sampling}

The tick specimen were massed from the specific area of HCNP, where high movement of Chiltan goat was observed. Fully fed ticks usually detached themselves from the host body and fell on the ground [14]. The collected specimens were preserved in $30 \%$ ethanol and brought to the laboratory, Department of Zoology, UOB, Quetta for examination.

\section{Temporary whole mount of ticks}

The specimen were softened by boiling them in $10 \%$ solution of sodium hydroxide $(\mathrm{NaOH})$. These were passed through a series of different grades (30, 50, 70, 90 and $100 \%$ aqueous solutions) of ethyl alcohol for dehydration, then transferred into pure xylene for clarification. Then enough Canada balsam over tick on a glass slide was put and cover slip was applied for temporary mount of the specimens. For better examination ticks were also placed in $1 \%$ acetic acid.

\section{Identification of specimens}

Taxonomical study of specimens were performed under light microscope $(\mathrm{CH}-4$ Olympus, Japan) on $8 \mathrm{X}, 10 \mathrm{X}$ and $40 \mathrm{X}$ magnification. The tick specimens were identified up to genus and species level by using relevant taxonomic keys described by Hoogstraal and Wassef [15].

\section{Results}

The isolation of ectoparasites (Ixodidae) from wild goat in HCNP, Quetta is the first attempt as no data has previously been found on the subject matter. Tick species were collected from the ground area of HCNP where high mobility of chiltan goats were observed. It can be assumed in the light of given literature that fully or partially engorged ticks might shed from chiltan wild goats [16]. Highest incidence of tick parasite was noted in the months of May and October of the study year 2016 when daily maximum, minimum average temperature and precipitation were $29^{\circ} \mathrm{C}$, $11^{\circ} \mathrm{C}, 7 \%$ and $25^{\circ} \mathrm{C}, 4^{\circ} \mathrm{C}$ and $1 \%$ respectively (Table 1). According to Bowman [18] several abiotic features especially temperature and humidity seldom may perhaps grow up ectoparasites such as fleas, lice and in specific ticks on the skin and wool of wild goat which may cause severe skin abrasions.

In total as many as 121 ticks belong to two genera and four species were detected from the animal host (Table 2). These were identified as Hyalomma anatolicum, $H$. excavatum, Rhipicepalus (Boophalus) microplus, and $R$. (B.) appendiculatus. Out of total tick counts, 87 were male and 34 were female specimens. Over all sex-wise ticks infestation indicated $(78 \%)$ for male compare to female tick species $(45 \%)$. The average prevalence of male ticks indicated high infestation of $R$. (B) appendiculatus (100\%) and $R$. (B.) microplus (100\%), followed by $H$. excavatum (57.14\%) respectively. The female ticks mean prevalence showed high infestation of $H$. anatolicum (46\%), and $H$. excavatum (43\%) respectively. Female ticks of $R$. (B) appendiculatus and $R$. (B.) microplus were not observed. 
Haneef et al.

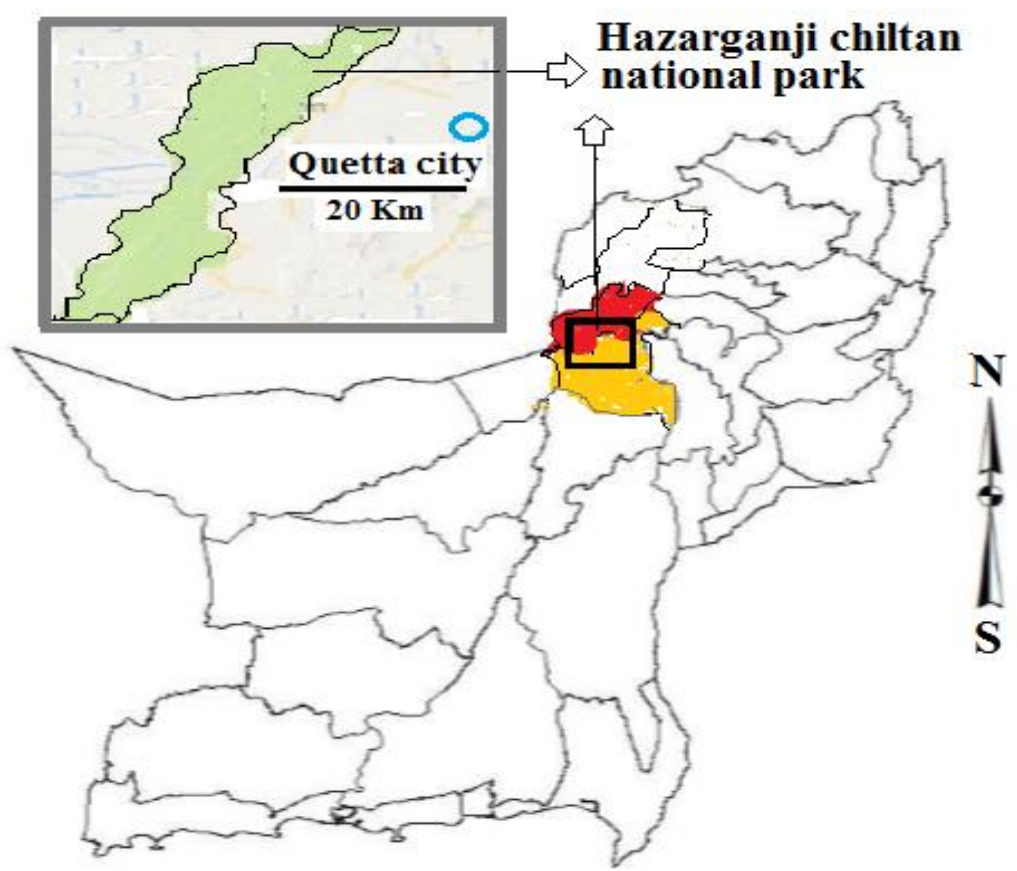

Figure 1. Districts of Quetta (Red) \& Mustang (Yellow) in map of Balochistan province

Table 1. Average temperature and precipitation of HCNP calculated during the study year 2016

\begin{tabular}{|c|c|c|c|c|}
\hline \multirow[b]{2}{*}{ Months } & \multicolumn{2}{|c|}{ Average daily temperature } & \multirow{2}{*}{$\begin{array}{c}\text { Average } \\
\text { precipitation } \\
(\mathrm{mm})\end{array}$} & \multirow{2}{*}{$\begin{array}{l}\text { Probability that a } \\
\text { month will be dry } \\
(\%)\end{array}$} \\
\hline & $\begin{array}{c}\text { Maximum } \\
\left(\mathbf{C}^{\circ}\right)\end{array}$ & $\underset{\left(\mathbf{C}^{\circ}\right)}{\operatorname{Minimum}}$ & & \\
\hline January & 7 & -12 & 37 & 15 \\
\hline February & 10 & -8 & 43 & 23 \\
\hline March & 18 & 3 & 42 & 38 \\
\hline April & 23 & 7 & 12 & 85 \\
\hline May & 29 & 11 & 7 & 100 \\
\hline June & 38 & 15 & 1 & 100 \\
\hline July & 40 & 20 & 18 & 92 \\
\hline August & 34 & 17 & 4 & 100 \\
\hline September & 31 & 10 & 1 & 100 \\
\hline October & 25 & 4 & 1 & 100 \\
\hline November & 12 & 0 & 6 & 86 \\
\hline December & 8 & -2 & 23 & 38 \\
\hline
\end{tabular}

Table 2. Sex-wise total count of tick species identified from chiltan wild goat in the present study during 2016

\begin{tabular}{|c|c|c|c|c|c|c|}
\hline S. No. & Tick species & $\begin{array}{c}\text { Total No. of } \\
\text { ticks collected }\end{array}$ & Male & $\begin{array}{c}\text { Average } \\
(\boldsymbol{\%})\end{array}$ & Female & $\begin{array}{c}\text { Average } \\
(\%)\end{array}$ \\
\hline 1 & Hyalomma anatolicum & 48 & 26 & 54.16 & 22 & 46 \\
\hline 2 & Hyalomma excavatum & 28 & 16 & 57.14 & 12 & 43 \\
\hline 3 & $\begin{array}{c}\text { Rhipicephalus (Boophalus) } \\
\text { microplus }\end{array}$ & 15 & 15 & 100 & 0 & 0 \\
\hline 4 & $\begin{array}{c}\text { Rhipicephalus (B.) } \\
\text { appendiculatus }\end{array}$ & 30 & 30 & 100 & 0 & 0 \\
\hline \multicolumn{2}{|c|}{ Total average (\%) infestation } & & & 78.0 & & 32.3 \\
\hline
\end{tabular}




\section{Discussion}

Data on ectoparasite of chiltan wild goat is meagre. However, numerous abiotic features may possibly grow up arthropodal ectoparasites like lice, fleas and in particular ticks on the coat and wool of wild goat which may cause severe skin abrasions and lesions [18]. These may further lead to secondary contagious microbial infections. The welfare of animals are generally influenced by these ectoparasites, being a zoonotic vector ticks also helps in distribution of many diseases [18]. They predominantly belong to the suborder Ixodida (ticks), and orders Siphonaptera (fleas) and Phthiraptera (lice).

Initial study on the population census of the chiltan wild goat were made in the early seventies. Schaller and Mirza [19] estimated the population of the chiltan goat as two hundred in Hazarganji-Chiltan National Park. In the course of developing the management plan, four separate surveys were conducted by WWF-Pakistan during 1996-1998 and on an average, more than seven hundred animals were counted in these surveys. Basic population and ecological data on the chiltan wild goat is extremely limited. Shafique et al. [20] explained wild life of Hazarganji chiltan national park.

In the present study during 2016 the ectoparasites (ticks) of Capra aegagrus chialtanensis were identified as Hyalomma anatolicum (Figure 1a, 1b), H. excavatum, (Figure 2a, 2b), Rhipicephalus (Boophalus) microplus (Figure 3a), and $R$. (B.) appendiculatus (Figure 3b). Rahbari and Nabian [21] reported Rhipicephalus (Boophilus) kohlsi [22] for the first time from wild goats (Capra hircus aegagrus) in Iran. These results are partially in line with our results. Asmaa et al. [23] determined tick infestations in ruminants under field conditions and reported $30.1 \%$ tick infestation with highest rate in cattle $(60.5 \%)$ than goats $(25.9 \%)$. Boophilus annulatus was the most prevalent $(26.5 \%)$ tick's species affecting ruminants than Hyalomma anatolicum $(6.1 \%)$ and Rhipicephalus turanicus $(3.4 \%)$, these results are similar to some extent with our findings. The overall number of wild goats were counted as 749 animals including mature male and female, lamb and trophy. On the health and welfare of this marvelous species not a single report has been published, nor in the past had any significant works been done on the subject matter in HCNP, Quetta, thus constituting a geographic record. Near the park area native people also reported the domestic herd of goats (Capra aegagrus hercus) grazing there, perhaps the ectoparasites might be spreaded from domestic herd to chiltan wild goat herds.

Ticks and tick-borne diseases are known to be the prime risk exploit animal's health status and spread various viral, bacterial and protozoan infections $[24,25]$. They also cause nuisance and irritation to fellow animals initiating severe injury to skin. Fleas also act as a major carrier of some pathogenic microbes like Bartonella, Yniaersi, and Rickettsia of familiar human and animal hosts. They cause serious skin reactions and allergies and may leads to microbial ill health [26]. Lice spread swine pox and often act as main reservoir of pathogens like Rickettsia [27], their bite often end in anemia and skin sensitivity that leads to severe allergy.

In the present study a bird called Alpine chough (Aves: Corvidae) was also observed in the HNCP area sitting on the back of chiltan wild goats. Local people named it 'Chagha', they believe that high population of twin lamb may occur during next season due to this bird prey upon ectoparasites of chiltan wild goat. It may be a symbiotic relationship as the birds benefit from the food source provided by the goat and the wild goat benefit in having extra eyes and ears to detect danger and sound the alarm. This clearly indicates that wild goats might have tendency to encourage the ectoparasite population [28]. 

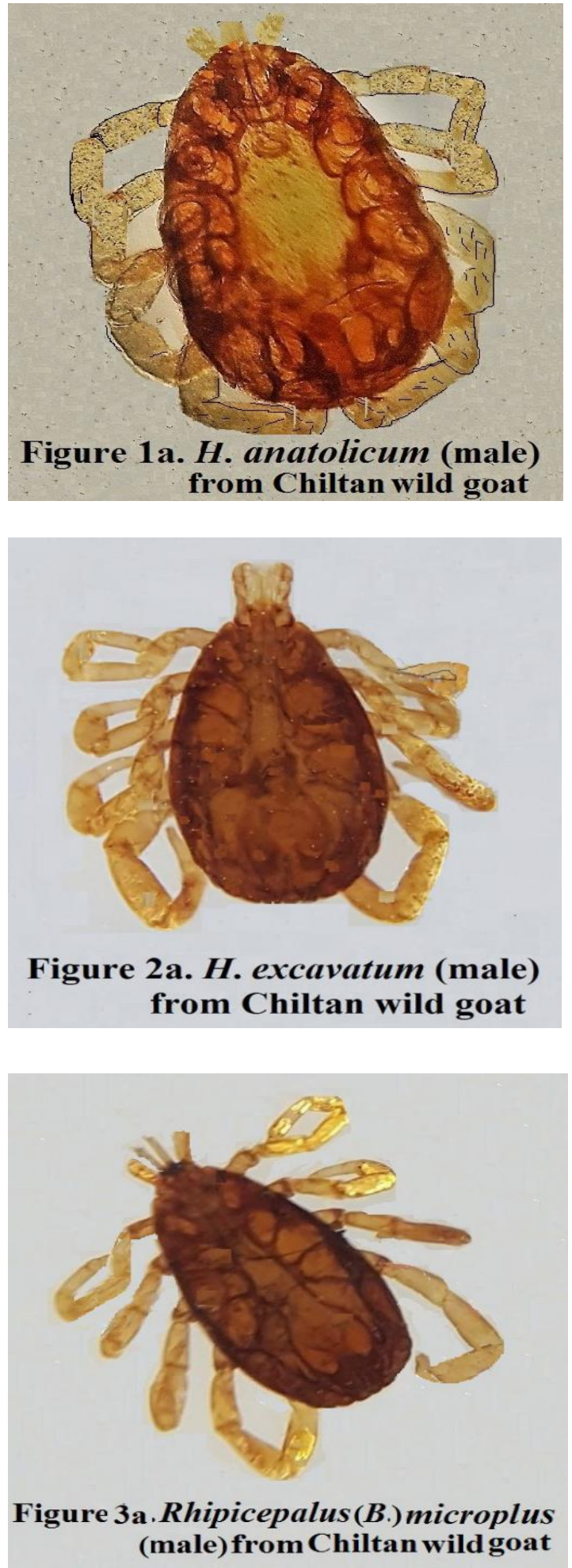

\section{Authors' contributions}

Conceived and designed the experiments: M Haneef \& A Kakar, Performed the experiments: M Haneef \& A Kakar, Analyzed the data: M Nasim, M Rafique \& N Ahmad, Contributed materials/ analysis/ tools: M Haneef, B Kakar \& S Din, Wrote the paper: A Kakar \& M Haneef.

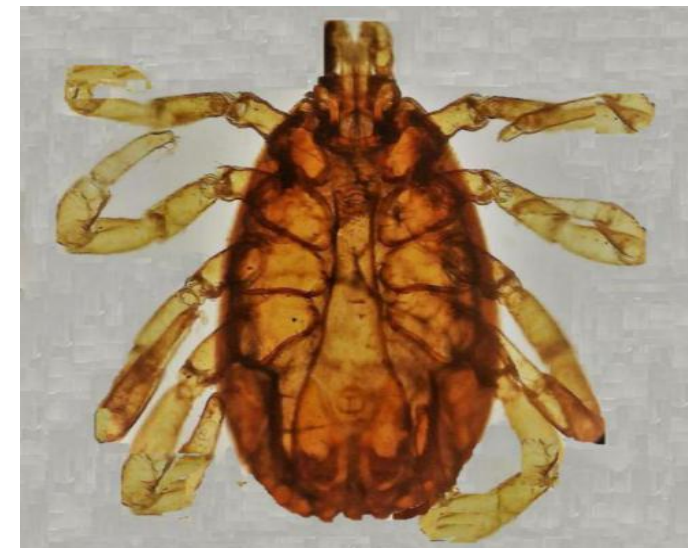

Figure 1b. H. anatolicum (female)
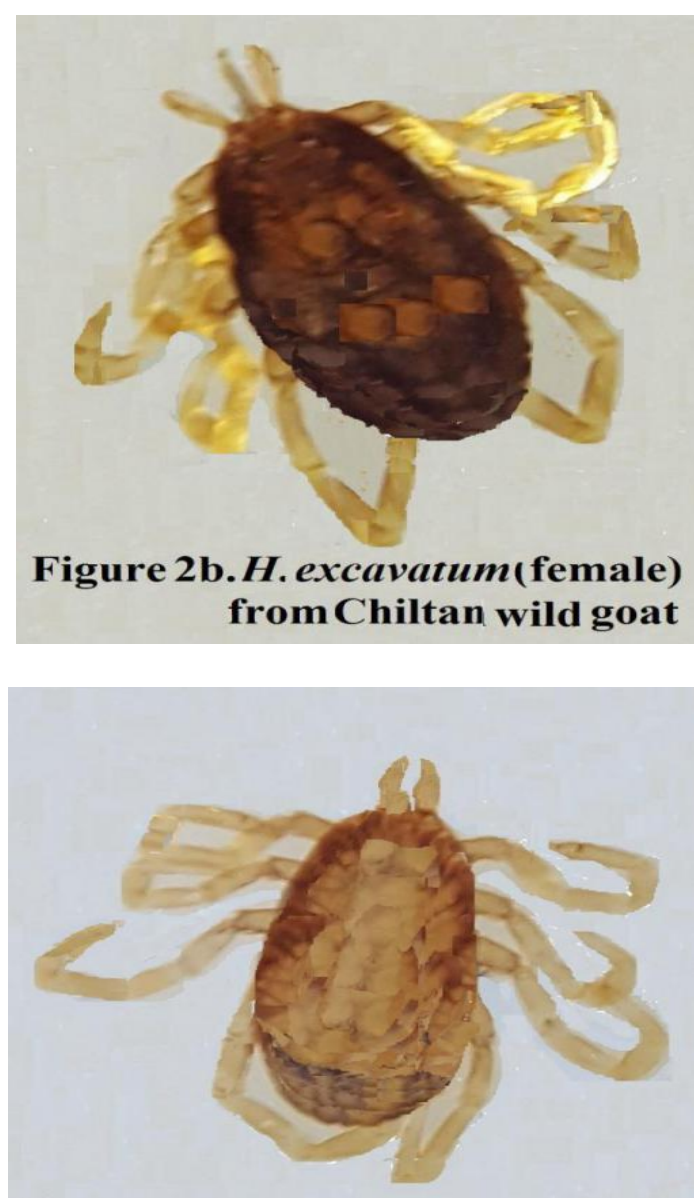

Figure 3b. R. (B.) appendiculatus (male) from Chiltan wild goat

\section{References}

1. Mirza ZB (1975). A census of Chiltan Markhor Capra hircus in Chiltan range, Quetta. Pak J Zool 7: 214-216.

2. Kakakhel SFB, Ullah A \& Rashid A (2017). Population and distribution of Flare Horned Markhor (Capra falconeri falconeri Wagner 1839) in 
District Swat, Khyber Pakhtunkhwa, Pakistan. Pak J Zool 49(2): 747-750.

3. Ahmed AV, Classeva A, Kitanova S \& Genov P (2016). Bezoar wild goat (Capra aegagrus Erxleben, 1777) history and opportunities for development of the species in Bulgaria. J Ani Vet Advan 6: 171-175.

4. Geskos A (2013). Past and present distribution of the genus Capra in Greece. Acta Theriologica 58 (1): 111.

5. Pidancier N, Jordan S, Luikart G \& Taberlet P (2006). Evolutionary history of the genus Capra (Mammalia, Artiodactyla): Discordance between mitochondrial DNA and Ychromosome phylogenies. Mol Phylogen Evol 40:739 -749.

6. Ahmad A \& Beg AR (1989). A report on the floral and faunal characteristics of the newly established Hingol and Drun National Parks in Baluchistan. Wildlife Management Branch, Pakistan Forest Institute, Peshawar, Pakistan.

7. Virk AT (1991). Management plan for wild ungulates in Balochistan, Pakistan. The University of Montana.

8. Lydekker R (1913). Catalogue of the ungulate mammals in the British museum (Natural History). Vol 1. London, British museum.

9. Roberts TJ (1969). A note on Capra falconeri (Wagner 1839). Zeit. Fur saugetierkunde, Bd. 34(4): 283-249.

10. Schaller GB (1977). Mountain monarchs. Wild sheep and goats of the Himalaya.Univ Chicago press, pp 111412.

11. Schaller, G.B \& Khan SA (1975). The status and distribution of Markhor (Capra falconeri). Biol Cons 7: 185198.

12. Bouattour A, Darghouth MA \& Daoud A (1999). Distribution and ecology of ticks (Acari: Ixodidae) infesting livestock in Tunisia: an overview of eighth years field collections. Parassitologia 41 Suppl 1:5-10.
13. Ashuma, Sharma A., Singla, LD, Kaur P, Bal MS, Batth BK \& Juyal PD (2013). Prevalence and haematobiochemical profile of Anaplasma marginale infection in dairy animals of Punjab (India). Asian Pac J Trop Biomed 6: 139-144.

14. Asmaa NM, El Bably MA \& Shokier KA (2014). Studies on prevalence, risk indicators and control options for tick infestation in ruminants. Beni-Suef University J Basic Appl Sci 3(1): 68-73.

15. Hoogstraal H, Wassef HY (1979). Haemaphysalis (Allophysalis) Kopetdaghica: identity and discovery of each feeding stage on the wild goat in northern Iran (Ixodoidea: ixodidae). J Parasitol 8: 783-790.

16. Hoogstraal H, Valdez R (1980). Ticks (Ixodoidea) from wild sheep and goats in Iran and medical and veterinary implications. Zool 6: 24-29.

17. Rahbari S, Nabian S (2007). The First Report of Rhipicephalus (Boophilus) kohlsi (Hoogstraal and Kaiser 1960) from Wild Goats (Capra hircus aegagrus) in Iran. Iranian J Parasitol 2(2): 53-56.

18. Bowman D D (2009). Georgis' Parasitology for Veterinarians. $9^{\text {th }}$ Ed. Saunders Elsevier, USA.

19. Waladde SM \& Rice MJ (1982). The sensory basis of tick feeding behaviors. In: obenchian. D and Galun R editors, Physiology of ticks. Pergamon Press, Oxford, pp 43-70.

20. Rosamond SCH \& Edmonds JW (1973). Observations of ectoparasites of wild rabbit Oryctolagus cuniculus (L.) in the Werribee district of Victoria. J Aust Ent Soc 12: 195-200.

21. Schaller GB \& Mirza ZB (1971). Observation on Urial and Markhor in West Pakistan. Unpublished report for government of Pakistan.

22. Shafique CM, Hassan A \& Arian QN (1997). Wildlife of Chiltan Hazargange National Park, Balochistan. WWF Pakistan pp 43. 
23. Hoogstraal H \& Kaiser MN (1960). Boophilus kohlsi n. sp. (Acarina: Ixodidae) from sheep and goats in Jordan. J Parasitol 46: 441-448.

24. Ahmed J, Alp H, Aksin M \& Seitzer U (2007). Current status of ticks of Asia. Parasitol Res 101(2): 159-162.

25. Talley J (2015). External parasites of goats. In: Oklahoma cooperative extension fact sheets, Oklahoma State University pp 1-8.

26. Dieme C, Parola P, Guernier V, Lagadec E, Le Minter G, Balleydier E, Pagès F, Dellagi K, Tortosa P, Raoult D \& Socolovschi C (2015). Rickettsia \& Bartonella species in fleas from
Reunion Island. The American J Trop Med \& Hyg 92(3): 617- 619.

27. Wolf MS (2010). Air Force Entomology Efforts during Operation Pacific Angel: Philippines, 2010. Proceedings of the Department of Defense (DoD) Symposium Global, Diverse, and Improving Public Health. DoD Entomology: Entomol Soc Amer San Diego CA. pp 47-51.

28. Neil P (1998). Hazarganji-Chiltan National Park Management plan, Compiled under contract by the World Wide Fund for Nature - Pakistan for the Forestry Department of the Government of Balochistan. pp 1-34. 